\title{
Observations on tocopherol absorption by pigs
}

\author{
By W. R. H. DUNCAN, G. A. GARTON, I. McDONALD AND W. SMITH \\ Rowett Research Institute, Bucksburn, Aberdeen
}

(Received 7 December 1959)

Garton, Duncan, Madsen, Shanks \& Beattie (1958) reported that, as judged by serum values, tocopherol in the form of Rovimix E (Roche Products Ltd) was apparently not absorbed by pigs when it was included in an otherwise tocopheroldeficient ration almost devoid of fat. It was thus not possible to confirm the finding of Bratzler, Loosli, Krukovsky \& Maynard (1950) that supplementing such a deficient diet with mixed tocopherols led to the formation of depot fat containing more oleic acid than was found in pigs not given the supplement.

The experiments of Garton et al. (1958) did not preclude the possibility that the simultaneous digestion and absorption of dietary fat may be a prerequisite for the intestinal absorption of tocopherol after its administration as Rovimix E. Hence the experiment now reported was designed to investigate the effect of adding the vitamin to pig diets with and without dietary fat in the form of lard. Lard was chosen because the commercial product is similar in its degree of unsaturation (iodine value) to that of the back fat of experimental pigs fed on a diet of low fat content, and thus it would be possible to observe an effect on back-fat composition caused by the addition of dietary tocopherol, if it is assumed that the absorbed lard glycerides are deposited in the animals' fat depots.

The Rovimix $\mathrm{E}$ as used by Garton et al. (1958) consisted of a powder containing $10 \%$ of DL- $\alpha$-tocopheryl acetate adsorbed on a silica base. It was hoped to use this material again, but unfortunately it was no longer available from the manufacturers. Instead a new form of Rovimix $\mathrm{E}$ was used in which DL- $\alpha$-tocopheryl acetate constitutes $10 \%$ by weight of a powder preparation containing starch, sucrose and gelatin. In addition, trials were made with gelatin capsules containing DL- $\alpha$-tocopheryl acetate and arachis oil in the proportions of $2: 1$ by weight.

\section{EXPERIMENTAL}

\section{Animals and diet}

Thirty-six pigs were used, six from each of six litters; each litter provided three male and three female animals, except one litter which provided four males and two females. One pig from each litter was allocated at random, as shown in Table $\mathrm{r}$, to each of six treatment groups in all of which the animals were fed from weaning on a slightly restricted feeding scale (Lucas \& Calder, 1955). Three breeds, Landrace $\times$ Wessex, Large White $\times$ Wessex, and Wessex were represented. The pigs in three treatment groups ( 1,2 and 3 ) were given the same basal low-fat, low-tocopherol diet 
as used by Garton et al. (1958) and those in the other three treatment groups (4, 5 and 6) received the same diet except that in it $5 \%$ of lard (iodine value $56 \cdot 0$ ) replaced $5 \%$ of the sucrose. Instead of the concentrate of vitamins $A$ and $D_{3}$ which was included in the diet used by Garton et al. (1958) another fat-free preparation, Rovimix $\mathrm{A}+\mathrm{D}_{3}$ (Roche Products Ltd), was used to give 1500 i.u. vitamin A and 375 i.u.

Table 1. Plan of experiment showing allocation to treatment groups and breed, sex and weight of the weanling pigs used

(See text for details of treatments)

\begin{tabular}{|c|c|c|c|c|}
\hline $\begin{array}{l}\text { Treatment } \\
\text { graup }\end{array}$ & Sex & $\begin{array}{l}\text { Weight } \\
\text { at weaning } \\
\text { (lb) }\end{array}$ & $\begin{array}{l}\text { Weight at } \\
\text { slaughter } \\
\text { (lb) }\end{array}$ & $\begin{array}{c}\text { Days on } \\
\text { experiment }\end{array}$ \\
\hline \multicolumn{5}{|c|}{ Litter A (Landrace $\times$ Wessex) } \\
\hline $\mathbf{I}$ & శే & 50 & 132 & 56 \\
\hline 2 & $0^{*}$ & 37 & $14 \mathrm{I}$ & 77 \\
\hline 3 & $q$ & 46 & 142 & 68 \\
\hline 4 & $0^{*}$ & 52 & 144 & 56 \\
\hline 5 & 우 & 58 & 157 & 56 \\
\hline 6 & $q$ & 48 & 135 & 56 \\
\hline \multicolumn{5}{|c|}{ Litter B (Landrace $\times$ Wessex) } \\
\hline $\mathbf{I}$ & $\sigma$ & 38 & 137 & 77 \\
\hline 2 & $0^{*}$ & 53 & 132 & 56 \\
\hline 3 & 우 & 53 & 128 & 56 \\
\hline 4 & q & 53 & 133 & 56 \\
\hline 5 & $\sigma^{\pi}$ & 52 & 136 & 56 \\
\hline 6 & q & 52 & I 44 & 56 \\
\hline \multicolumn{5}{|c|}{ Litter C (Landrace $\times$ Wessex) } \\
\hline I & q & 44 & $\mathbf{1 4 3}$ & 68 \\
\hline 2 & $\sigma$ & 28 & 125 & 77 \\
\hline 3 & $q$ & 47 & 142 & 68 \\
\hline 4 & $\pi$ & 43 & I45 & 68 \\
\hline 5 & 우 & 35 & I $3 \mathbf{I}$ & 68 \\
\hline 6 & o & $4^{\circ}$ & 140 & 77 \\
\hline \multicolumn{5}{|c|}{ Litter D (Large White $\times$ Wessex) } \\
\hline $\mathbf{I}$ & 8 & 45 & 140 & 70 \\
\hline 2 & $q$ & $4 I$ & 130 & 70 \\
\hline 3 & o & 55 & 144 & $6 \mathrm{I}$ \\
\hline 4 & q & 38 & 126 & 70 \\
\hline 5 & $\sigma^{*}$ & 53 & 126 & 49 \\
\hline 6 & 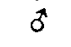 & $5 \mathrm{I}$ & 127 & 49 \\
\hline \multicolumn{5}{|c|}{ Litter E (Wessex) } \\
\hline I & q & 40 & 129 & 70 \\
\hline 2 & $\vec{a}$ & 40 & 138 & 81 \\
\hline 3 & $\bar{a}$ & 34 & 114 & 81 \\
\hline 4 & $q$ & 39 & 132 & 70 \\
\hline 5 & $\sigma^{*}$ & 48 & I 33 & 61 \\
\hline 6 & $q$ & 42 & 141 & 70 \\
\hline \multicolumn{5}{|c|}{ Litter F (Wessex) } \\
\hline $\mathbf{I}$ & 우 & 40 & I3I & 70 \\
\hline 2 & q & $4 I$ & 129 & 70 \\
\hline 3 & 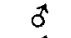 & 47 & 131 & 61 \\
\hline 4 & 0 & 49 & I4 1 & 61 \\
\hline 5 & $q$ & 44 & I3I & $6 \mathrm{I}$ \\
\hline 6 & a & 50 & r 33 & 6I \\
\hline
\end{tabular}


vitamin $\mathrm{D}_{3}$ per $\mathrm{lb}$ feed. For convenience the diets with and without lard will subsequently be referred to as the lard diet and basal diet, respectively.

By analysis, the basal diet contained $16.6 \%$ crude protein, $0.7 \%$ ether-extractable matter and $1.5 \mathrm{mg}$ total tocopherols/100 g diet, and the lard diet contained $16.2 \%$ crude protein, $5 \cdot 7 \%$ ether-extractable matter and $1 \cdot 5 \mathrm{mg}$ total tocopherols/roo $\mathrm{g}$ diet.

Two treatment groups (groups $I$ and 4 ) served as controls and the animals in the other groups were given $20 \mathrm{mg}$ DL- $\alpha$-tocopheryl acetate/kg body-weight/day. The animals were weighed weekly and, on this basis, the amount of tocopheryl-acetate preparation (as Rovimix E or in capsules) required daily per pig for the ensuing week was calculated.

The pigs of each litter were housed together and the diet was given individually as a wet mash daily at $7.0 \mathrm{a} . \mathrm{m}$. and $4.0 \mathrm{p} . \mathrm{m}$., the supplement being added as required to the $4.0 \mathrm{p} . \mathrm{m}$. feed. The Rovimix $\mathrm{E}$ was mixed, as supplied, in the feed for the pigs in treatment groups 2 and 5. The daily allowance for each pig in treatment groups 3 and 6 was made up from gelatin capsules containing $5^{\circ}$ or $25^{\circ} \mathrm{mg}$ tocopheryl acetate per capsule (see p. 371) which were thoroughly shaken in $100 \mathrm{ml}$ warm water to dissolve the gelatin; the resulting mixture was added to the wet mash in the animal's feeding trough. It was originally intended to mix the capsules themselves with the food mash, but during the ist week of the experiment when this method was tried some were left uneaten and had to be forcibly administered.

After 8-10 weeks on the experimental diets when the pigs weighed about 120-140 lb (Table $\mathrm{I}$ ) they were slaughtered at a bacon factory; the time of slaughter was arranged to be $17-18 \mathrm{~h}$ after the last feed containing tocopherol for pigs in treatment groups 2,3 , 5 and 6.

\section{Examination of tissues}

Tissue samples. At slaughter the livers and samples of blood and back-fat tissue were obtained, the latter as described by Garton et al. (1958). Blood, taken into heparinized receivers, was centrifuged to obtain plasma. Back-fat tissue was carefully dissected into its inner and outer layers. Pieces of each liver were examined histologically.

Chemical methods. Immediately after the plasma samples had been obtained sodium ascorbate $\left(25^{\circ} \mathrm{mg} / 100 \mathrm{ml}\right)$ was added as an anti-oxidant; they were then stored at $-20^{\circ}$ for $3^{-6}$ weeks. For tocopherol assay $10 \mathrm{ml}$ of thawed plasma were mixed with $10 \mathrm{ml}$ absolute ethanol in a separating funnel; $25 \mathrm{ml}$ of light petroleum (A.R., b.p. $40-60^{\circ}$ ) were added and the mixture was shaken vigorously for $2 \mathrm{~min}$.

After settling, the light-petroleum extract was carefully removed by Pasteur pipette and the extraction was repeated. The combined light-petroleum extracts were distilled to dryness under nitrogen on a warm water-bath. The lipid thus obtained was treated as recommended by the Society for Analytical Chemistry: Vitamin-E Panel of the Analytical Methods Committee (1959) for the determination of total tocopherols (taken in this experiment to be entirely $\alpha$-tocopherol). Tocopherol was similarly determined in the fats extracted, as described by Garton et al. (1958), from the outer back-fat tissues of the pigs of litters $A$ and $F$.

Iodine values of all the back fats were determined by the Wijs method as described by Hilditch (1949). 


\section{RESULTS}

The plasma-tocopherol values at slaughter of the pigs in the six groups and tocopherol values for the back fats of the pigs of litters $\mathrm{A}$ and $\mathrm{F}$ are given in Table 2.

As Table 2 shows, the mean plasma-tocopherol values were significantly higher for treatment groups $2,3,5$ and 6 (i.e. those groups given tocopherol as Rovimix E or in solution in arachis oil) than in the two groups given no supplementary tocopherol $(P<$ o.oor $)$. There was no significant difference between the mean values for treatment groups $\mathrm{I}, 2$ and 3 given the basal diet and those for the corresponding groups given the lard diet. The effect on plasma-tocopherol values of the tocopherol supplementation did not depend on whether it was given as Rovimix $\mathrm{E}$ or in solution in

Table 2. Plasma tocopherol values $(\mu \mathrm{g} / \mathrm{ro0} \mathrm{ml})$ at slaughter of the pigs in the six treatment groups and tocopherol contents $(\mu \mathrm{g} / \mathrm{g})$ of the outer back fats of the pigs in litters $A$ and $F$

\begin{tabular}{|c|c|c|c|c|c|c|c|c|c|}
\hline \multirow{3}{*}{$\begin{array}{l}\text { Treatment } \\
\text { group }\end{array}$} & \multicolumn{6}{|c|}{ Plasma tocopherol } & \multirow[b]{3}{*}{ Mean } & \multirow{2}{*}{\multicolumn{2}{|c|}{$\begin{array}{c}\text { Back-fat } \\
\text { tocopherol } \\
\text { Litter }\end{array}$}} \\
\hline & \multicolumn{6}{|c|}{ Litter } & & & \\
\hline & A & B & $\mathrm{C}$ & $\mathbf{D}$ & $\mathrm{E}$ & $\mathbf{F}$ & & A & $\mathbf{F}$ \\
\hline $\mathbf{I}$ & ro & 20 & 60 & 73 & 49 & II2 & 54 & 2 & 2 \\
\hline 2 & 385 & 442 & 442 & 483 & 499 & $\mathbf{2 8 7}$ & 423 & 21 & 34 \\
\hline 3 & 550 & 483 & 608 & 368 & 387 & 355 & $45^{8}$ & 19 & 23 \\
\hline 4 & 58 & 33 & 43 & 141 & 0 & 4 & 46 & 6 & 4 \\
\hline 5 & 508 & 663 & 442 & 450 & 508 & 327 & 483 & 10 & 20 \\
\hline 6 & $35^{8}$ & 390 & 287 & 533 & $38_{3}$ & 340 & 382 & 8 & 15 \\
\hline
\end{tabular}

Standard error of differences between treatment means for plasma, \pm 50 .

arachis oil or on whether or not lard was included in the diet. There was also no suggestion that the sex or breed of the pig affected the results. An analysis of covariance of plasma-tocopherol values on the length of time each pig was on the experiment showed no significant residual correlation and thus there was no need to adjust the results for differing times on experiment.

The tocopherol values for back fats (Table 2) showed a pattern according to treatment group similar to that of the plasma values.

The iodine values of the inner and outer back fats are shown in Table 3. Though the mean iodine values of both inner and outer back fat were significantly higher in the treatment groups given the lard diet $(P<0.001)$, there were no significant differences between the mean values for treatment groups $I$ and 4 (i.e. those not given supplementary tocopherol) and those for the corresponding groups given a tocopherol supplement. The effect of the lard diet was not significantly influenced by the presence of either form of supplementary tocopherol.

Since the mean time on experiment was less for the pigs on the lard diet than for the others, it was necessary to determine whether the difference in their iodine values was related to this difference in time. An analysis of covariance showed a significant residual correlation for both outer and inner back fats $(P<0.05)$. For every additional day taken to reach slaughter weight, these iodine values were each reduced on 
average by 0.1 units (standard error \pm 0.04 ). However, only minor adjustments to the mean back-fat iodine values for each treatment group were required to eliminate this effect of differences in time on experiment and the results remained substantially as given in Table 3 .

Table 3. Iodine values of the inner and outer back fats of the pigs in the six treatment groups

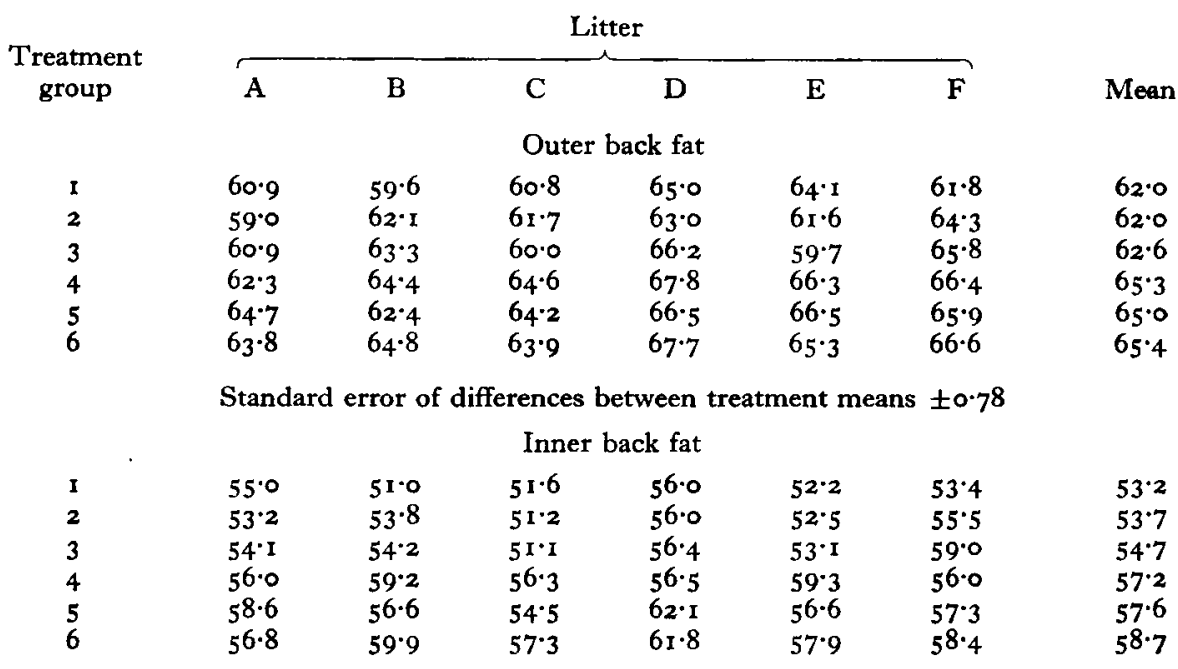

Standard error of differences between treatment means \pm 0.97

\begin{tabular}{|c|c|c|c|c|c|}
\hline \multirow{3}{*}{ Litter means } & \multicolumn{5}{|c|}{ Outer back fat } \\
\hline & & & $62 \cdot 5 \quad 66 \cdot 0$ & $63 \cdot 9$ & $65 \cdot 1$ \\
\hline & $55^{\cdot 6}$ & $55 \cdot 8$ & $53 \cdot 7$ & $55 \cdot 3$ & $6 \cdot 6$ \\
\hline
\end{tabular}

There was no significant sex difference in mean iodine value of either inner or outer back fat, but there were significant differences from litter to litter in outer back fat $(P<0.001)$ and to a lesser extent in inner back fat $(P<0.01)$. Since these differences coincided to a large extent with the breed differences they may have been due to breed effects rather than to litter differences, but the number of litters concerned was insufficient to decide this point.

At slaughter the livers appeared normal macroscopically, though histological examination showed a slight to moderate degree of interlobular cirrhosis to be present in the livers of almost all the animals. The carcasses were all accepted for human consumption.

\section{DISCUSSION}

Contrary to the findings of Garton et al. (1958) that the inclusion of Rovimix $\mathrm{E}$ in a pig ration of very low fat content did not affect serum-tocopherol values, the values obtained in this experiment (Table 2) show that tocopherol is absorbed as effectively from an almost fat-free diet as from one containing $5 \%$ of lard. Thus the suggestion of Garton et al. (1958) that the absorption of dietary tocopherol might be dependent on the simultaneous digestion and absorption of dietary lipids is not true when the 
tocopherol is supplied in mixture with starch, sucrose and gelatin or in solution in very small amounts of arachis oil.

In agreement with the observations of Dammers, Stolk \& van Wieringen (1958) tocopherol was stored to some extent in depot fat (Table 2). Our work does not support the contention of Bratzler et al. (1950) that supplementation with tocopherol results in an increase in the proportion of oleic acid relative to that of saturated fatty acids in pig depot fats. Supplementation of the basal or lard diet by tocopherol, amount and duration being similar to those in the experiment of Bratzler et al. (1950), had no effect on the unsaturation of the back fats.

Garton \& Duncan (1954) showed that, on a diet very rich in lard, the pig can absorb and incorporate dietary triglycerides into its back fat without any appreciable change in fatty-acid composition. It was assumed that the same was likely to occur in the present experiment though the amount of lard ingested was considerably less than that consumed by the pigs used by Garton \& Duncan (1954). Thus the observation that the feeding of lard per se led to the formation of back fats having a significantly higher iodine value than was observed in animals given the basal diet was unexpected. The effect was apparent although the iodine value of the lard $(56 \cdot 0)$ was lower than that of the outer back fat $\left(62^{\circ} \cdot 0\right)$ of the pigs fed on the basal diet; when the lard was added to this diet a significantly higher value of over 65.0 was recorded (Table 3 ). The inner back fats showed a similar change in iodine value. No explanation can at present be offered to account for this apparently selective deposition of lard glycerides. It is, of course, not precluded that some degree of hydrolysis of the lard glycerides took place in the intestine or elsewhere and that the resulting fatty acids were selectively incorporated into newly synthesized glycerides.

Though most of the livers showed some degree of interlobular cirrhosis it was no more marked in the pigs not given supplementary tocopherol than in the others and the condition was therefore not specially associated with any of the experimental treatments.

The use of a randomized block design in this experiment to eliminate litter effects from treatment comparisons was justified by the results; as shown in Table 3 there were substantial differences in mean iodine values of back fats from litter to litter.

\section{SUMMARY}

I. Six groups, each of six weanling pigs, representing three breeds, were fed for 8-1o weeks on a basal low-fat, low-tocopherol diet or on a similar diet containing $5 \%$ of lard; each diet was given with and without supplementary DL- $\alpha$-tocopheryl acetate. The supplement was given either as Rovimix E (Roche Products Ltd) in which the tocopheryl acetate forms $10 \%$ of a powder containing starch, sucrose and gelatin or as a solution containing two parts of tocopheryl acetate in one part of arachis oil. The supplemented pigs received $20 \mathrm{mg}$ tocopheryl acetate $/ \mathrm{kg}$ body-weight/day.

2. At slaughter the plasma-tocopherol values of the pigs given supplementary tocopherol were significantly higher than those of the unsupplemented animals. The effect of tocopherol supplementation did not depend on the form in which the toco- 
pherol was given or on whether or not lard was included in the ration. Thus the absorption of the dietary tocopherol was not dependent on the simultaneous digestion and absorption of fat.

3. The degree of unsaturation of the inner and outer back fats was not influenced by the tocopherol supplement. This observation is not in agreement with the findings of Bratzler et al. (1950). The iodine values of the back fats were, however, significantly higher in the pigs given the lard diet. This unexpected finding implies a selective incorporation into the fat depots of the lard glycerides or fatty acids for which no explanation can at present be offered.

4. Histological examination of the livers, with particular reference to the animals not given supplementary tocopherol, showed no significant abnormalities.

We are indebted to Roche Products Ltd for their generous gift of Rovimix E, Rovimix $A$ and $D_{3}$ and the gelatin capsules of tocopheryl acetate. We also wish to thank Mr G. H. Clement (Roche Products Ltd) for valuable discussion, Mr B. F. Fell (Pathology Department of this Institute) for the histological examination of livers and Mr R. M. Livingstone (Applied Nutrition Department of this Institute) for advice and assistance.

\section{REFERENCES}

Bratzler, J. W., Loosli, J. K., Krukovsky, V. N. \& Maynard, L. A. (1950). Э. Nutr. 42, 59.

Dammers, J., Stolk, K. \& van Wieringen, G. (1958). Versl. landb. Onderz., 's Grav. no. 64.5.

Garton, G. A. \& Duncan, W. R. H. (1954). Biochem. F. 57, 120.

Garton, G. A., Duncan, W. R. H., Madsen, K. A., Shanks, P. L. \& Beattie, I. S. (1958). Brit. F. Nutr. I2, 97.

Hilditch, T. P. (1949). The Industrial Chemistry of the Fats and Waxes, 3rd ed., p. 47. London: Baillière, Tindall and Cox.

Lucas, I. A. M. \& Calder, A. F. C. (1955). F. agric. Sci. 46, 307.

Society for Analytical Chemistry: Vitamin-E Panel of the Analytical Methods Committee (1959). Analyst, 84, 356 . 